\title{
IMPLEMENTASI GEMAR MENGAJI DALAIM PEMBINAAN BACA TULIS AL-QUR'AN PERSPEKTIF PENDIDIKAN ISLAM DI KECAMATAN MARIORIWAWO KABUPATEN SOPPENG
}

\author{
Satturi \\ Mahasiswa Pascasarjana UIN Alauddin Makassar \\ Email: satturiwardah@gmail.com
}

\begin{abstract}
The purpose of this research is: 1) To know the description of the implementation of studying in the District of Marioriwawo Soppeng District, 2) To examine the reading ability of al-Qur'an learners on the implementation of study in the District of Marioriwawo, Soppeng Regency, 3) obstacles and solutions faced in the implementation of learning the Qur'an in fond of Mengaji in District Marioriwawo Soppeng District in an effort to build literacy Qur'an.

This research is descriptive qualitative research with approach of study that is normative, pedagogical, and sociological theology. The data source of this research consisted of government, teacher of Koran, and community figure in District of Marioriwawo of Soppeng Regency as informant. Data collection techniques were conducted by conducting interviews of observation and documentation. Processing techniques and qualitative data analysis using 3 stages are 1) data reduction, 2) display data, and 3) conclusion.

The result of the research shows that, firstly, the description of the implementation of studying in the District of Marioriwawo, Soppeng Regency is very smooth and the teachers in the District of Marioriwawo, Soppeng District has played an active role in teaching al-Qur'an and developing several methods, and provide effective guidance so that learners can develop optimally in accordance with their potential, and create an environment in the District of Marioriwawo Soppeng religious district. Second, the ability to read al-Qur'an learners on the implementation of fond memories in District Marioriwawo Soppeng District which contains activities that are operational ie; systematic actions and learning, targets to be achieved or desired by government and society, and the activities of the described to instill Qur'anic values to achieve the goals. Third, the constraints and solutions encountered in the implementation of learning the Qur'an in fond of Mengaji in District Marioriwawo Soppeng District in an effort to learn and write al-Qur'an; the first attitude of ignorance of parents to their children in motivating reading and writing al-Qur'an and the influence of technology $(H P)$ is very fast and the participation of parents in the reading and writing of the Qur'an is very minimal. The solution in overcoming the constraints faced namely; parental attitudes in motivation, limited technological influence of HP, intensive guidance, additional tasks of learners, and increased teacher incentives to review and improve training for teachers.

The implication of this research is that the educator in Marioriwawo Subdistrict of Soppeng Regency still needs the intensity of reading al-Qur'an and need additional teaching materials of tajwid and makharijul letters, as an insight and provision to develop and applied in the middle of society, it is expected to keep the teacher istiqamah pay attention to reading learners in District Marioriwawo
\end{abstract}


Soppeng district that in fact is good in terms of practice, and need to be improved in terms of material, so that the quality of both in terms of materials and practices can be in line.

Keywords: Fond of Koran, Read the Qur'an

\section{PENDAHULUAN}

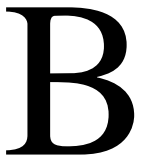

egitu pentingnya membaca al-Qur'an dengan baik dan benar, sehingga membaca al-Qur'an dengan baik menjadi salah satu syarat menjadi seorang imam shalat yakni tidak salah ucap (membaca al-Qur'an) sehingga merusak makna di waktu membaca al-Fatihah dan bukan seorang yang ummi, yaitu tidak bisa membaca al-Fatihah dengan baik sedangkan makmumnya bisu pula.

Jika al-Qur'an dipandang sebagai mukjizat Nabi Muhammad saw. yang paling besar dan abadi, serta pedoman hidup manusia untuk mencapai kebahagiaan duniaakhirat, maka sudah seharusnya cara membaca al-Qur'an diatur sedemikian rupa, sehingga pembaca mendapat berkahnya, baik berkah yang bersifat hissi maupun yang bersifat maknawi.

Membaca al-Qur'an pun tak bisa dikatakan memenuhi kaidah tajwid dan Makharijul Huruf jika tidak dilakukan langsung dihadapan seorang guru atau syaikh, sebab sangat banyak kaidah dalam bacaan al-Qur'an yang memang harus diluruskan cara membacanya melalui talaqqi (bertemu langsung) dan musyafahah (pembetulan letak bibir saat membacanya). Itu belum termasuk sekian banyak kalimat yang memang baru bisa diketahui dnegan benar cara membacanya saat talaqqi dan musyafahah.

Kesalahan membaca akan mengubah lafazh dalam al-Qur'an. Dan perubahan lafazh secara otomatis akan membawa kepada perubahan bacaan atau qira'at. Perbedaan qira'at dalam al-Qur'an ada yang berpengaruh dan ada yang tidak dalam pengambilan hukum. Contohnya yaitu, dalam lafazh waarjulikum dan waarjulakum. Walaupun tidak berpengaruh dalam pengambilan hukum, perubahan lafazh akan menyebabkan arti atau makna yang dikandung al-Qur'an tersebut berbeda.

\section{METODE PENELITIAN}

Penelitian ini adalah penelitian deskriptif kualitatif dengan pendekatan studi yaitu teologis normatif, pedagogis, dan sosiologis. Sumber data penelitian ini terdiri atas pemerintah, guru mengaji, dan tokoh masyarakat di Kecamatan Marioriwawo Kabupaten Soppeng sebagai informan. Teknik pengumpulan data dilakukan dengan melakukan wawancara observasi dan dokumentasi. Teknik pengolahan dan analisis data kualitatif menggunakan 3 tahapan yaitu 1) reduksi data, 2) display data, dan 3) pengambilan kesimpulan. 


\section{HASIL PENELITIAN DAN PEMBAHASAN}

Gambaran implementasi gemar mengaji di Kecamatan Marioriwawo Kabupaten Soppeng yaitu: program tersebut baik dan lancar serta guru-guru mengaji di Kecamatan Marioriwawo Kabupaten Soppeng telah berperan aktif dalam mengajarkan al-Qur'an dan mengembangkan beberapa metode termasuk motode latihan pada peserta didik sehingga perubahan fungsi dan peran secara subtansial. Orientasi pelaksanaan pembelajaran membaca al-Quran dengan program gemar mengaji meliputi; Pertama, meningkatkan mutu dan memberikan bimbingan secara efektif, sehingga peserta didik dapat berkembang secara optimal sesuai dengan potensi yang dimiliki, kedua, menciptakan lingkungan di Kecamatan Marioriwawo Kabupaten Soppeng yang religius, ketiga, menumbuhkan penghayatan terhadap nilai-nilai al-Quran dan ajaran agama serta budaya bangsa sehingga menjadi sumber kearifan dalam bertindak, keempat, mengembangkan standar pencapaian ketuntasan, serta meningkatkan prestasi ekstrakurikuler, dan kelima, meningkatkan persamaan dalam bidang pendidikan alQur'an.

Kemampuan membaca al-Qur'an peserta didik pada pelaksanaan gemar mengaji di Kecamatan Marioriwawo Kabupaten Soppeng baik kegiatan tersebut berisikan kegiatan-kegiatan yang bersifat oprasional yaitu; Tindakan dan pembelajaran yang sistematis, Target yang akan dicapai atau diingini oleh pemerintah dan masyarakat, Kegiatan mengaji yang digambarkan untuk menanamkan nilai-nilai Qur'ani untuk mencapai tujuan. bahwa berdasarkan hasil penelitian kemampuan membaca al-Qur'an peserta didik di Kecamatan Marioriwawo Kabupaten Soppeng, bahwa setiap peserta didik memiliki tingkat kemampuan yang berbeda-beda dan hanya berapa peserta didik yang dikategorikan predikat kurang, dan yang lainnya lebih banyak masuk pada kategori sedang dan baik. Kiat-kiat untuk memelihara bacaan dan bahkan hafalan alQuran adalah Materi yang sudah hafal hendaknya diperdengarkan (disima') kepada orang lain yang ahli.dan Untuk memperkokoh hafalan hendaklah dilakukan tadarusan (mudarosah) atau simak menyimak bersama para penghafal lainnyayang menjadikan kita aktif membacanya.

Kendala-kendala dan solusi yang dihadapi dalam implementasi gemar mengaji di Kecamatan Marioriwawo Kabupaten Soppeng dalam upaya pembinaan baca tulis alQur'an yaitu; pertama Sikap acuh orangtua terhadap anaknya dalam memotivasi membaca dan menulis al-Qur'an, pengaruh teknologi (HP) sangat kencang dan Keikutsertaan orang tua dalam pembinan baca tulis al-Qur'an sangat minim, sedangkan fada faktor pragmatis kendala yang dihadapi yaitu; sarana prasarana yang kurang memadai dan masih banyaknya guru mengaji yang masih mengunakan pola-pola lama dalam mengajarkan al-Qur'an dan kurangnya insentif guru mengaji, dan Solusi mengatasi kendala-kendala yang dihadapi dalam Implementasi gemar mengaji di Kecamatan Marioriwawo Kabupaten Soppeng yaitu; Melakukan bimbingan secara Intensif, Memberikan pekerjaan rumah atau tugas tambahan peserta didik, 
Mengintensifkan latihan membaca, dan memberikan motivasi secara intensif, Menjadikan mesjid sebagai tempat belajar mengaji, meningkatkan insentif guru mengaji dan meningkatkan pelatihan bagi guru-guru mengaji di Kecamatan Marioriwawo Kabupaten Soppeng.

\section{PENUTUP}

Gambaran implementasi gemar mengaji di Kecamatan Marioriwawo Kabupaten Soppeng sangat lancar dan guru-guru mengaji di Kecamatan Marioriwawo Kabupaten Soppeng telah berperan aktif dalam mengajarkan al-Qur'an dan mengembangkan beberapa metode termasuk motode latihan gemar mengaji meliputi peningkatan mutu dan memberikan bimbingan secara efektif sehingga peserta didik dapat berkembang secara optimal sesuai dengan potensi yang dimiliki, dan menciptakan lingkungan di Kecamatan Marioriwawo Kabupaten Soppeng yang religius. Kedua, kemampuan membaca al-Qur'an peserta didik pada pelaksanaan gemar mengaji di Kecamatan Marioriwawo Kabupaten Soppeng yang berisikan kegiatan-kegiatan bersifat operasional yaitu; tindakan dan pembelajaran yang sistematis, target yang akan dicapai atau diingini oleh pemerintah dan masyarakat, dan kegiatan mengaji yang digambarkan untuk menanamkan nilai-nilai Qur'ani untuk mencapai tujuan. Ketiga, kendala-kendala dan solusi yang dihadapi dalam implementasi pembelajaran al-Qur'an pada gemar Mengaji di Kecamatan Marioriwawo Kabupaten Soppeng dalam upaya pembinaan baca tulis alQur'an yaitu; pertama sikap acuh orang tua terhadap anaknya dalam memotivasi membaca dan menulis al-Qur'an serta pengaruh teknologi (HP) sangat cepat dan keikutsertaan orang tua dalam pembinan baca tulis al-Qur'an sangat minim. Adapun solusi dalam mengatasi kendala-kendala yang dihadapi yaitu; sikap orang tua dalam memberikan motivasi, pengaruh teknologi HP dibatasi, melakukan bimbingan secara intensif, memberikan tugas tambahan peserta didik, serta meningkatkan insentif guru mengaji dan meningkatkan pelatihan bagi guru-guru mengaji. Penelitian ini yaitu pendidik di Kecamatan Marioriwawo Kabupaten Soppeng masih sangat membutuhkan intensitas baca tulis al-Qur'an dan membutuhkan tambahan materi pembelajaran ilmu tajwid dan makharijul huruf, sebagai wawasan dan bekal untuk mengembangkan sekaligus diaplikasikan ditengah-tengah masyarakat, diharapkan kepada pengajar agar tetap istiqamah memperhatikan bacaan peserta didik di Kecamatan Marioriwawo Kabupaten Soppeng yang notabene sudah bagus dari segi praktek, dan perlu ditingkatkan dari segi materi, supaya kualitas baik dari segi materi dan praktek bisa sejalan. 


\section{DAFTAR PUSTAKA}

Al-Qur'an al-Karim

Ahmadi, Abu. Cara Belajar yang Mandiri dan Sukses. Solo: Aneka, 1993.

Ali, Muhammad. Penelitian Kependidikan Prosedur dan Strategi Cet. III; Bandung: Angkasa, 1985.

-------. Strategi Penelitian Pendidikan Cet. II; Bandung Angkasa, 1993.

Amaliyah, Rizki Ayu. "Adab Membaca Alquran Studi Kasus Santri Tahfidz Qur'an As‘adiyah Qurra wa al-Huffadz Masjid Agung Sengkang”. Skripsi Makassar: Fakultas Ushuluddin Filsafat dan Politik UIN Alauddin, 2015.

Annuri, Ahmad. Panduan Tahsin Tilawah al-Qur'an \& Ilmu Tajwid. Cet. I; Jakarta: Pustaka Al-Kautsar, 2010.

Aziz, Abdul al-Rauf al-Hafidh. Kiat Sukses Menjadi Hafizd al-Qur'an. Bandung: Syamil, 2004.

Badudu. Kamus Besar Bahasa Indonesia Jakarta : Depdiknas, 1994.

Badwilan, Ahmad Salim. Seni Menghafal alquran Cet.I; Solo: Wacana Ilmiah Press, 2008.

Baharuddin. "Pengaruh Pendidikan al-Qur'an terhadap Pembinaan Mental/Akhlak Peserta didik SMP Negeri 3 Sinjai Tengah Kabupaten Sinjai Tesis Program Pascasarjana UIN Alauddin Makassar, 2011.

Al-Bukhari Muhammad bin Isma'il bin Ibrahim bin al-Mughirah. Shahih al-Bukhari. Juz V Cairo: Darul Fikri, 1981.

Bungin, Burhan. Analisis Data Kualitatif: Pemahaman Filosofis dan Metodologis ke Arah Penguasaan Model Aplikasi. Cet. III; Jakarta: Rajawali Press, 2009.

Djamarah, Syaiful Bahri dan Aswan Zain. Strategi Belajar Mengajar. Jakarta: Rineka Cipta, 2002.

Djamarah, Syaiful Bahri. Psikologi Belajar. Jakarta: PT. Rineka Cipta, 2002.

Echols, John M. dan Hassan Shadily. Kamus inggris Indonesia Cet. XXVI; Jakarta: Gramedia, 2005.

Embas, Aisyah Arsyad. Rekonstruksi Metotologi Tahfiz alquran. Cet.I; Makassar: Alauddin University Press, 2011.

Gade, Fithriani. 2014. "Implementasi Metode Takrār Dalam Pembelajaran Menghafal Al-Qur'an”, Jurnal Ilmiah Didaktika Vol. Xiv no. 2, 413-425.

Gie, Liang. Cara Belajar Yang Efesien . Yogyakarta: Pusat Kemajuan Studi, 1988. 
Hasan, Alwi. dkk. Kamus Besar Bahasa Indonesia Edisi ketiga.Balai Pustaka: Jakarta, 2002.

Al-Hilali, Salim Ied. al-Salihi Syarah Riyad. Terj. Abd. Ghoffar. Bogor: Pustaka Imam al-Syafi'i, 2003.

Ibrahim, Rasma Gafar."Peranan Taman Pendidikan al-Qur'an pada Sekolah Dasar dalam Meningkatkan Minat Baca Tulis al-Qur'an di Kecamatan Murhum Kota Bau-Bau” Tesis Program Pascasarjana Universitas Alauddin Makassar, 2009

Ismail, Abu Fida. Lubab al-Tafsir min Ibni Katsir. Terj. Abdul Goffar, Tafsir Ibnu Katsir Cet. I; Bogor: Pustaka Imam al-Syafi’e, 2004.

Tafsir Ibnu Katsir, Terj. Abdul Gofar. Jakarta: Pustaka 6 Imam al-Syafi’i, 2004.

Ivancevich \& Gibson. Organisasi dan Manajemen Perilaku, Struktur, Proses. Cet. IV; Jakarta: Airlangga, 1994.

Al-Ja'fary, Imam Abu 'Abdillah Muhammad bin Ismail bin Ibrahim bin Mugiroh Barzabah al-Bukhori Juz 5, Bab Fad\}oil Qur'an, Shahih Bukhari. Bairut-Libanon: Darul Fikri, 855 H.

John W., Creswell. Research Design Qualitative \& Quantitative Approaches. New delhi: Sage, 1994.

-------. Qualitative Inquiry and Research Design: Choosing among Five Tradition. London: Sage Publications, 1998.

Kementerian Agama RI. Al-Qur'an dan Terjemahnya. Jakarta: PT Sinergi Pustaka Indonesia, 2012.

Kementerian Pendidikan dan Kebudayaan RI. Kamus Besar Bahasa Indonesia. Cet. IV; Jakarta: Pusat Bahasa, 2008.

Khouiru, Lif Ahmadi dkk. Strategi Pembelajaran Sekolah Terpadu: Pengaruhnya terhadap Konsep. Mekanisme dan Proses Pembelajaran Sekolah Swasta dan Negeri. Cet. I; Jakarta: Prestasi Pustaka Publisher, 2012.

Komaruddin. Kamus Istilah Skripsi dan Tesis. Bandung: Angkasa, 2009.

Kriyantono, Rachmat. Teknik Praktis Riset Komunikasi. dengan kata pengantar oleh Burhan Bungin. Edisi Pertama Cet. IV; Jakarta: Kencana, 2009.

Ma'rifat, M. Hadi. Sejarah al-Qur'an. Cet. II; Jakarta: Al Huda, 2007.

Ma'luf, Luwis. al-Munjid fi al-Lugah. Beirut: Dar al-Masyriq, 1977.

Marzuki. Metodologi Riset. Yogyakarta: t. pn, 2008.

Moleong, Lexy J. Metodologi Penelitian Kualitatif. Bandung: Remaja Rosdakarya, 2013. 
------. Metodologi Penelitian Kualitatif. Cet. XXVII; Bandung: Remaja Rosdakarya, 2010.

------. Metodologi Penelitian Kualitatif. Cet. XXV; Bandung Remaja: Rosdakarya, 2008.

Mudhofar, Muhlis. “Strategi Pembelajaran Tahfidzul Qur'an Di Pondok Pesantren Darul Ulum Boyolali”. Tesis. Surakarta: Program Pascasarjana Institut Agama Islam Negeri Surakarta, 2017.

Muhajir, Neong. Metodologi Penelitian kualitatif. Cet. VIII; Yokyakarta: Rake Selatan, 1998.

Muharram, Zulfisun. Belajar Mudah Membaca al-Qur'an dengan Metode Mandiri. Cet. I; Jakarta: Ciputat Press, 2003.

Al-Munawar, Said Agil Husain. Aktualisasi Nilai-nilai Qur`an Dalam Sistem Pendidikan Islam. Cet. I; Jakarta : Ciputat Press, 2003.

Munjahid. Strategi Menghafal Alquran 10 Bulan Khatam: Kiat-kiat Sukses Menghafal Alquran. Yogyakarta: Idea Press, 2007.

MZ. A. Suad dan Muhammad Sidiq. Mutiara Alquran. Sorotan Alquran terhadap Berbagai Teknologi Modern. Cet. I; Surabaya: Al-Ikhlas, 1988.

Al-Naisabury, Imam Abu Husain Muslim bin Hajjaj al-Khusairi, Shohih Muslim, Bab. Fadlu al Qiraatil Qur'an wasuratul Baqarah Kitabul Salatul Musafirin Wakasruha. Juz I, Hadits 252 Cet. I; Darul ’Alimil Kutubi: Riyadh, 1996 M/1417 $\mathrm{H}$.

Nasution, S. Metode Research. Jakarta: Bumi Aksara, 2007.

Nata, Abuddin. Manajemen Pendidikan Mengatasi Kelemahan Pendidikan Islam di Indonesia. Bogor: Kencana, 2003.

------. Perspektif Islam tentang Strategi Pembelajaran. Cet. II; Jakarta: Kencana, 2012.

Nawabuddin, Abdurrab. Teknik Menghafal Alquran. Bandung: Al-Gesindo, 1991.

Nawawi, Maria Ulfah. Pedoman Ilmu Tajwid. Surabaya: Karya Abditama, 1995.

Norma, Ali. Urgensi Ilmu Tajwid dalam memasyarakatkan al-Qur'an Jakarta: alQushwa, 2005.

Nur Qadirun, Al-Shabuni. Muhammad Ali. Ikhtisar Ulumul Qur'an Praktis. trjm. Muhammad. Jakarta; Pustaka Amani, 2001.

Pasanreseng, Yunus. Sejarah Lahir dan Pertumbuhan Pondok Pesantren As'adiyah Sengkang Sengkang. Pengurus Besar As'adiyah, 1992.

Pascasarjana UIN Alauddin Makassar, Pedoman Penulisan Karya Ilmiah 2014- 2015. 
Al-Qattan, Manna Khalil. Mabahis $\backslash$ Fi Ulum al-Qur'an, Terj. Aunur Rafiq, Pengantar Studi Ilmu al-Qur'an. Cet. IV; Jakarta; Pustaka al-Kautsar, 2009.

Rakhmat, Jalaluddin. Metode Penelitian Komunikasi: Dilengkapi Contoh Analisis Statistik. Cet. XIII; Bandung: PT Remaja Rosdakarya. 2007.

Sa'dulloh, Metode Praktis Menghafal al-Qur'an. Cet. I; Sumedang: Ponpes al-Hikamussalafi Sukamantri, 2005.

Al-Salih,Subhi. Mabahis $\backslash$ Fi Ulum al-Qur'an, Terj. Tim Pustaka Firdaus, Membahas Ilmu- Ilmu al-Quran. Cet IX, Jakarta: Pustaka Firdaus, 2004.

Salim, Ahmad Badwilan. Panduan Cepat Menghafal Al Quran. Jogjakarta: Diva Press, 2009.

Sastrapradja, M. Istilah pendidikan dan Umum untuk Guru-guru. Surabaya: Usaha Nasional, 1978.

Al-Shabuni, Muhammad Ali. Ikhtisar Ulumul Qur'an Praktis. trjm. Muhammad.

Shihab Quraish, Wawasan al-Qur'an Tafsir Maudhu'i oleh Berbagai Persoalan Umat. Bandung: Mizan, 2007.

Sugiyono. Metode Penelitian PendidikanPendekatan Kualitatif, Kualitatif, dan R\&D. Bandung: Alfabeta, 2008.

Sukmadinata, Metode Penelitian Pendidikan. Cet. I; Bandung: Rosdakarya, 2006.

Suriadi, Andi. Tajwid Qiro'ah, Cara Cepat Belajar dan Mengajar Tajwid Tanpa Menghafal. Makassar: Yayasan Foslamic, 2012.

Syarifuddin, Ahmad. Mendidik Anak, Membaca, Menulis dan Mencintai al-Qur'an. Jakarta: Gema Insani, 2004,

Thalib, Muhammad. Fungsi dan Fadhilah Membaca al-Qur'an. Surakarta: Kaffah Media, 2005.

Ulfah, Nawawi Maria. Pedoman Ilmu Tajwid. Surabaya: Karya Abditama, 1995.

Wahyudi, Moh. Ilmu Tajwid Plus. Surabaya: Halim Jaya, 2007. 